Scientia Agricola

http://dx.doi.org/10.1590/0103-9016-2013-0401

\title{
Salinomycin and virginiamycin for lactating cows supplemented on pasture
}

Isis Scatolin de Oliveira1 ${ }^{*}$, Daniel de Paula Sousa², Augusto Cesar de Queiroz¹, Bruna Gomes Macedo², Camila Garcia Neves², Isabela Eloisa Bianchi², Ronyatta Weich Teobaldo²

${ }^{1}$ Federal University of Viçosa - Dept. Animal Science, Av. P.H. Rolfs, s/n - 36570-000 - Viçosa, MG - Brazil.

${ }^{2}$ Federal University of Mato Grosso - Dept. Basics Sciences and Animal Production, Av. Fernando Corrêa da Costa, 2367

- 78060-900 - Cuiabá, MT - Brazil.

*Corresponding author <isisscatolin@hotmail.com>

Edited by: Gerson Barreto Mourão

Received July 31, 2014

Accepted February 16, 2015
ABSTRACT: Animals on pasture generally show higher feed efficiency as a result of the use of antibiotics. This study evaluated the effect of the antimicrobials salinomycin and/or virginiamycin on production and the ruminal parameters of supplemented dairy cows grazing on Panicum maximum cv. Tanzania. Twelve Holstein/Zebu multiparous cows were used, distributed in three Latin squares, one for the evaluation of ruminal parameters, and the others for production parameters. Cows on pasture were fed $50 \%$ of their estimated intake with corn silage and concentrate supplements containing salinomycin, virginiamycin or a combination of additives, in doses of 120 and $150 \mathrm{mg} \mathrm{kg}^{-1}$, respectively. There were no differences in milk production and composition, energy and nitrogen balance, dry matter digestibility and feeding behavior. However, salinomycin and virginiamycin each reduced pasture and total dry matter intake by about $14 \%$ and $10 \%$, with a consequent improvement in feed efficiency.

Keywords: Panicum maximum, digestibility, feeding behavior, ionophores, nitrogen balance

\section{Introduction}

Salinomycin, a polyester antibiotic ionophore produced by Streptomyces albus, has been effective in increasing the production of cattle on high-grain diets (Merchen and Berger, 1985) or on pasture (Bagley et al., 1988). The mechanism of action is related to the transport of high-affinity cations into the cell. This impairs the normal flux of ions through the cell membrane, and reduces the growth rates of susceptible microorganisms as a result of energy loss from the cell.

Produced during fermentation of Streptomyces virginiae, virginiamycin is an antibiotic belonging to the class of streptogramins. Composed of two factors, M and $\mathrm{S}$, with synergistic functions, virginiamycin can be linked specifically and irreversibly to ribosomal units. This inhibits peptide formation, with a consequent reduction in growth (bacteriostasis effect) or even death of bacteria (bactericidal effect) (Boon and Dewart, 1974).

Gram-negative microorganisms are generally resistant to ionophore and non-ionophore antibiotics, because their outer membrane is impermeable to many macromolecules. The increase of gram-negative bacteria in the rumen improves energy and protein status, due to the change in the ruminal fermentation pattern, which increases propionate production and reduces methane and deamination of amino acids (McGuffey et al., 2001). In dairy herds, reduction of non-esterified fatty acids, ketones and $\beta$-hydroxybutyrate, and increases in the availability of glucose and amino acids associated with these antibiotics have resulted in lower body-fat mobilization, and higher milk production, milk-protein content and feed efficiency (Erasmus et al., 2008).

Animals on pasture or fed with higher proportions of forage generally show poor responses to the use of antibiotics (Clayton et al., 1999). However, the use of combinations of antibiotics has increased feed efficiency and milk production, together with the reduction of metabolic problems associated with the use of body reserves (Erasmus et al., 2008).

The small number of experiments which use either salinomycin or virginiamycin, and also a combination of these antibiotics, suggested that useful information could be gained from an evaluation of the effects of these treatments on the physiological and production parameters of dairy cattle supplemented on pasture.

\section{Materials and Methods}

The experiment was conducted from February through April 2010 in Santo Antônio do Leverger, in the state of Mato Grosso, Brazil, at $141 \mathrm{~m}$ altitude, 15²51'56" $\mathrm{S}$ and $56^{\circ} 04^{\prime} 36^{\prime \prime} \mathrm{W}$. The climate was Cwa of Köppen, tropical, with two distinct seasons, a rainy summer (Oct through Mar) and a dry winter (Apr through Sep). The mean annual temperature and annual rainfall are $24^{\circ} \mathrm{C}$ and $1,300 \mathrm{~mm}$, respectively.

Twelve Holstein/Zebu multiparous dairy cows, after the peak of lactation, were used in three $4 \times 4$ Latin Square-design experiments, grouped according to the volume of milk production. The first group consisted of rumen-cannulated cows to evaluate nutritional parameters. These cows were producing $9 \mathrm{~kg} \mathrm{~d}^{-1}$ of milk and averaged $354 \pm 35 \mathrm{~kg}$ Body Weight (BW). The other two evaluated production parameters. These cows weighed on average $460 \pm 23$ and $514 \pm 32 \mathrm{~kg} \mathrm{BW}$ and were producing 13 and $15 \mathrm{~kg} \mathrm{~d}^{-1}$ of milk, respectively. The cows were adapted to each trial over an 11-day period. During this period, the cows were fed twice daily (06h30 and 15h30) with a total of $3 \mathrm{~kg}$ of the same supplement.

The experiment consisted of four experimental periods of 21 days each; the first 14 days were used for diet adaptation and the following seven for data collection. Animals kept on pasture were fed simultaneously at $7 \mathrm{~h} 00$ and $15 \mathrm{~h} 30$, after milking, with 
corn silage and concentrate supplement in individual feeders. Animals producing more than $10 \mathrm{~kg} \mathrm{~d}^{-1}$ of milk were fed $2.0 \mathrm{~kg}$ of concentrate supplement and an additional $1.0 \mathrm{~kg}$ per $2.5 \mathrm{~kg} \mathrm{~d}^{-1}$ of milk produced above the $10-\mathrm{kg}$ level. The amount offered comprised $50 \%$ of calculated daily intake according to the estimated dry matter intake (DMI) (NRC, 2001):

DMI $\left(\mathrm{kg} \mathrm{d}^{-1}\right)=\left(0.372 \times \mathrm{FCM}+0.0968 \times \mathrm{BW}^{0.75}\right)$ $*\left(1-\mathrm{e}^{(-0.192 \times(\mathrm{WL}+3.67))}\right)$, where $\mathrm{FCM}=4 \%$ Fat-corrected milk production $\left(\mathrm{kg} \mathrm{d}^{-1}\right)$; $\mathrm{BW}=$ body weight $(\mathrm{kg})$ and $\mathrm{WL}=$ weeks of lactation

The treatments consisted of additives, as follows: i) Control diet (C); ii) salinomycin $120 \mathrm{mg} \mathrm{kg}^{-1}$ of concentrate supplement (S); iii) virginiamycin $150 \mathrm{mg}$ $\mathrm{kg}^{-1}$ of concentrate supplement (V); and iv) salinomycin and virginiamycin 120 and $150 \mathrm{mg} \mathrm{kg}^{-1}$ of supplement (SV).

The experimental area consisted of 12 plots of Tanzania grass (Panicum maximum. Jacq. cv. Tanzania); each plot had an area of 2,500 $\mathrm{m}^{2}$ and was managed rotationally. Forage availability was estimated when the animals entered each paddock, by measuring the sward height at 20 points. Only paddocks with a mean initial sward height of $75 \mathrm{~cm}$ were used. The cows were removed when the sward height was reduced to approximately $40 \mathrm{~cm}$. During the experimental period, the pasture was fertilized with $88 \mathrm{~kg} \mathrm{ha}^{-1}$ of nitrogen and $88 \mathrm{~kg} \mathrm{ha}^{-1}$ of potassium.

Hand-plucked samples were collected simulating the grazing action. The forage, feed offered and residues were weighed and sampled daily in the last seven days of each period. Forage samples were cut at ground level, in an area defined by quadrats measuring $0.5 \times 0.5$ $\mathrm{m}$, homogenized and divided to determine fractions of green and dry leaf (leaf blade), green and dry stem (stem + sheath), and forage mass availability (kg DM ha $\left.{ }^{-1}\right)$ in each experimental paddock (Table 1).

Forage intake and food digestibility were estimated using external and internal markers. Fifteen grams $\mathrm{d}^{-1}$ of chromium oxide $\left(\mathrm{Cr}_{2} \mathrm{O}_{3}\right)$, administered orally to each cow from day 8 through 15 of each experimental period, was used as an external marker to estimate the fecal excretion of individual animals. Fecal samples were

Table 1- Morphological components of Tanzania-grass.

\begin{tabular}{|c|c|c|c|c|c|}
\hline & \multicolumn{4}{|c|}{ Period } & \multirow{2}{*}{ Means } \\
\hline & 1 & 2 & 3 & 4 & \\
\hline & \multicolumn{4}{|c|}{$\longrightarrow$ t DM ha ${ }^{-1}$} & \\
\hline Leaf & 3.50 & 3.59 & 2.78 & 2.02 & 2.97 \\
\hline Stem & 2.72 & 2.62 & 2.70 & 1.92 & 2.49 \\
\hline Senescent & 6.53 & 4.41 & 3.95 & 3.34 & 4.56 \\
\hline \multirow[t]{2}{*}{ Total } & 12.75 & 10.62 & 9.43 & 7.28 & 10.02 \\
\hline & 27.47 & 33.78 & 29.46 & 27.81 & 29.63 \\
\hline Stem & 21.33 & 24.66 & 28.63 & 26.39 & 25.25 \\
\hline Senescent & 51.20 & 41.56 & 41.88 & 45.84 & 45.12 \\
\hline Sward Height (cm) & 83.90 & 83.06 & 77.99 & 55.47 & 75.11 \\
\hline
\end{tabular}

collected directly from the rectum (approximately 200 g), on day 14 through 16 of the experimental period, at the following times: day 14 (17h00), 15 (11h00) and 16 (06h00).

The total digestible nutrients (TDN) and digestible (DE), metabolizable (ME) and net energy of lactation $\left(\mathrm{NE}_{\mathrm{L}}\right)$ were calculated according to the models proposed by NRC (2001). TDN g kg-1 = digestible crude protein (CP) + digestible neutral detergent fiber (NDF) + digestible non-fibrous carbohydrates (NFC) $+(2.25$ $\times$ digestible ether extract (EE)). DE Mcal kg-1 was estimated by multiplying the concentration of each digestible nutrient and its heat of combustion. ME Mcal $\mathrm{kg}^{-1}$ for experimental diets with less than $3 \%$ of ether extract was $\mathrm{ME}\left(\mathrm{Mcal} \mathrm{kg}^{-1}\right)=(1.01 \times \mathrm{DE})-0.45 . \mathrm{NE}_{\mathrm{L}}$ for experimental diets with less than $3 \%$ of ether extract was $\mathrm{NE}_{\mathrm{L}}\left(\mathrm{Mcal} \mathrm{kg}^{-1}\right)=0.703 \times \mathrm{ME}-0.19$.

Forage intake was estimated with indigestible NDF, using the following model proposed by Detmann et al. (2001). Forage $(\mathrm{DMI})=[(\mathrm{FE} \times \mathrm{MC})-\mathrm{MCS}] \mathrm{MCF}^{-1}$, where: $\mathrm{FE}=$ fecal excretion $\left(\mathrm{kg} \mathrm{d}^{-1}\right) ; \mathrm{MC}=$ marker content in feces $\left(\mathrm{kg} \mathrm{kg}^{-1}\right) ; \mathrm{MCS}=$ marker content in the supplement $\left(\mathrm{kg} \mathrm{d}^{-1}\right) ; \mathrm{MCF}=$ marker content in the forage $\left(\mathrm{kg} \mathrm{kg}^{-1}\right)$.

Samples of forage, ingredients, supplements, residues and feces were pre-dried in a forced-air oven at $60 \pm 5{ }^{\circ} \mathrm{C}$ for $72 \mathrm{~h}$, ground, and sifted through a sieve with a $1 \mathrm{~mm}$ mesh size. Each sample was analyzed for dry matter (DM), organic matter (OM), ash, CP, and $\mathrm{EE}$, as described by AOAC (2005) (Table 2). The

Table 2 - Proportion of ingredient of concentrate supplements and chemical composition of feeds.

\begin{tabular}{|c|c|c|c|}
\hline Ingredients (\%) & & \multicolumn{2}{|c|}{ Concentrate supplement } \\
\hline Ground corn & & & 71.75 \\
\hline Sunflower meal & & & 10.10 \\
\hline Soybean meal & & & 11.50 \\
\hline Limestone & & & 1.15 \\
\hline Dicalcium phosphate & & & 1.80 \\
\hline Urea/Ammonia sulphate & & & 2.50 \\
\hline Sodium chloride & & & 0.50 \\
\hline Molasses & & & 0.50 \\
\hline Mineral premix ${ }^{1}$ & & & 0.20 \\
\hline Composition & Tanzania grass & Corn Silage & Conc. supplement \\
\hline Dry Matter (\%) & 31.28 & 29.81 & 83.62 \\
\hline Ash (\% in DM) & 6.77 & 8.39 & 7.85 \\
\hline Crude Protein (\% in DM) & 14.32 & 6.74 & 27.47 \\
\hline Ether Extract ${ }^{1}$ (\% in DM) & 1.97 & 2.66 & 2.27 \\
\hline $\mathrm{NDFap}^{2}$ (\% in DM) & 61.24 & 53.57 & 15.82 \\
\hline $\mathrm{NFC}^{3}$ (\% in DM) & 15.68 & 28.63 & 47.17 \\
\hline
\end{tabular}

${ }^{1}$ Mineral premix composition: $105 \mathrm{~g} \mathrm{~kg}^{-1}$ of Calcium; 7,500 mg kg-1 of Magnesium; $230 \mathrm{~g} \mathrm{~kg}^{-1}$ of sulfur; $330 \mathrm{mg} \mathrm{kg}^{-1}$ of cobalt; $2000 \mathrm{mg} \mathrm{kg}^{-1}$ of Cupper; $155 \mathrm{~g} \mathrm{~kg}^{-1}$ of lodine; $2,800 \mathrm{mg} \mathrm{kg}-1$ of Magnesium; $220 \mathrm{mg} \mathrm{kg}^{-1}$ of Selenium; $6800 \mathrm{mg} \mathrm{kg}^{-1}$ of Zinc; Control treatment - no antibiotics; S - 120 $\mathrm{mg} \mathrm{kg}^{-1}$ of salinomycin; $\mathrm{V}-150 \mathrm{mg} \mathrm{kg}^{-1}$ of virginiamycin; SV - $120 \mathrm{mg} \mathrm{kg}^{-1}$ of salinomycin and $150 \mathrm{mg} \mathrm{kg}^{-1}$ of virginiamycin; ${ }^{2} \mathrm{NDF}_{\text {an }}$ (neutral detergent fiber corrected for ash and protein); ${ }^{3} \mathrm{NFC}$ (non fibrous carbohydrates) $=100-(\mathrm{CP}$ $\%$ - CP \% from urea + urea \%) + NDF \% + EE \% + Ash \%. 
contents of NDF were determined by using $\alpha$ amylase without sodium sulfite added, and corrected (NDFap), discounting ash and neutral detergent-insoluble protein (Mertens, 2002; Licitra et al., 1996). Due to the presence of urea, NFC was calculated as proposed by Hall (2000): $\mathrm{NFC}=100-(\mathrm{CP} \%-\mathrm{CP} \%$ derived from urea + urea $\%)$ $+\mathrm{NDF} \%+\mathrm{EE} \%+$ Ash $\%$.

Cows were milked twice daily at $06 \mathrm{~h} 00$ and $15 \mathrm{~h} 00$. Milk production was recorded through a milking device, from day 15 through 18 of each experimental period. On days 17 and 18, proportional morning and evening milk samples of approximately $100 \mathrm{~mL}$ were collected and packed in plastic bottles with preservative. The content of fat, protein and lactose were analyzed by infrared spectrophotometry (IDF, 1996). $3.5 \%$ fat-corrected milk production (FCM) was estimated (Sklan et al., 1992) by the following equation: FCM in $\mathrm{kg} \mathrm{d}^{-1}=(0.432 \times \mathrm{kg}$ milk) $+(16.216 \times \mathrm{kg}$ milk fat $)$.

Feed efficiency (FE) was calculated as fatcorrected milk production per total dry matter intake and energy efficiency $\left(\mathrm{EE}_{\mathrm{f}}\right)$ as Mcal of net energy of lactation excreted on milk per Mcal of net energy of lactation intake. Energy balance (EB, Mcal d-1) was calculated by subtracting the $\mathrm{NE}_{\mathrm{L}}$ consumed from the required amounts of net energy for maintenance and lactation. Net energy of maintenance $\left(\mathrm{NE}_{\mathrm{M}} ; \mathrm{Mcal}\right.$ $\mathrm{d}^{-1}$ ) was calculated as $0.080 \mathrm{x} \mathrm{BW}^{0.75}$ and net energy of lactation $\left(\mathrm{NE}_{\mathrm{L}} ; \mathrm{Mcal} \mathrm{d}^{-1}\right)=(0.0929 \times \%$ fat $+0.0547 \mathrm{x}$ $\% \mathrm{CP}+0.0395 \times \%$ lactose $) \times$ milk production $\left(\mathrm{kg} \mathrm{d}^{-1}\right)$ (NRC, 2001).

Animals were weighed every 21 days in each experimental period, after the morning milking. Blood samples were collected on day 21, and centrifuged to separate the serum. Urea was determined in deproteinized milk and serum using commercial kits (Labtest $\left.{ }^{\circledast}\right)$. Urea was converted to blood urea nitrogen by multiplying the observed values by 0.4667 , which gives the total nitrogen in the urea.

Urine spot samples were collected on day 21 of each period and stored at $-20{ }^{\circ} \mathrm{C}$ for total nitrogen analysis. The nitrogen balance was obtained from the difference between nitrogen intake and nitrogen excreted in feces, urine and milk.

Ruminal fluid was collected through the ruminal cannula on day 20 , to measure $\mathrm{pH}$ and ammonia concentration before (0) and 2, 4, 6 and $8 \mathrm{~h}$ after the beginning of feeding in the morning. Rumen fluid $\mathrm{pH}$ was immediately determined with the use of a digital potentiometer. At each sampling, a $50-\mathrm{mL}$ aliquot of the ruminal fluid from each animal was mixed with $1 \mathrm{~mL}$ of $50 \%$ sulfuric acid and stored at $-5{ }^{\circ} \mathrm{C}$ for ammonia analyses.

The feeding behavior was assessed on day 19, for $24 \mathrm{~h}$, by visual observation. Every ten minutes were recorded activities of grazing, ruminating and idle were recorded.

Data were statistically analyzed using PROC MIXED. The statistical model was:
$\mathrm{Y}_{\mathrm{ijkl}}=\mu+\mathrm{A}_{\mathrm{i}(1)}+\mathrm{P}_{\mathrm{j}(1)}+\mathrm{T}_{\mathrm{k}}+\mathrm{Q}_{1}+\mathrm{TQ}_{\mathrm{kl}}+\mathrm{e}_{\mathrm{ijk} \mathrm{k}_{+}}$

where: $\mathrm{Y}_{\mathrm{ijkl}}=$ observation of cow $\mathrm{i}$ in period $\mathrm{j}$ subject to supplementation level $\mathrm{k}$, in Latin square $l_{;} \mu=$ overall effect of the mean; $A_{\mathrm{i}(1)}=$ effect of animal $\mathrm{i}$ in Latin square 1 , where $\mathrm{i}=1,2,3,4 ; \mathrm{P}_{\mathrm{j}(1)}=$ effect of period $\mathrm{j}$ in Latin square 1 , with $\mathrm{j}=1,2,3,4 ; \mathrm{T}_{\mathrm{k}}=$ effect of supplementation level $\mathrm{k}$, where $\mathrm{k}=1,2,3,4 ; Q_{1}=$ effect of Latin square 1 , where $1=1,2 ; \mathrm{T}_{\mathrm{Okl}}=$ interaction effect between treatment $\mathrm{k} \times$ Latin square $\mathrm{l}_{i} \mathrm{e}_{\mathrm{ijkl}}=$ random error associated with each observation ijkl. eijkl NID (0. $\sigma 2)$. In the presence of a significant treatment effect, means were compared using Tukey's test, considering $\alpha$ $=5 \%$ and $10 \%$ for tendency of error type I.

\section{Results and Discussion}

The intake of supplements was not different $(p>$ $0.05)$ between the experimental diets $\left(5.72 \mathrm{~kg} \mathrm{~d}^{-1}\right)$, and was close to what was offered $\left(6 \mathrm{~kg} \mathrm{~d}^{-1}\right)$. Total DMI of cows receiving the control diet averaged $11.46 \mathrm{~kg} \mathrm{~d}^{-1}$, slightly lower than the level predicted by NRC (2001), about $12.03 \mathrm{~kg} \mathrm{~d}^{-1}$. Administration of salinomycin or virginiamycin reduced ( $p=0.03$ ) DMI by about $14 \%$ and $10 \%$, respectively, as the nutrients NDFap and TDN. Thus, the use of antibiotics reduced pasture intake and, at the same time, fiber intake, below the values suggested by Mertens (1987). According to this author, fiber intake is usually limited by rumen fill when NDF intake reaches approximately $1.2 \pm 0.1 \%$ of BW (Table 3).

Ipharraguerre and Clark (2003) observed that 8 out of 12 studies on monensin for lactating cows found no differences in DMI. Their findings demonstrate that ionophore responses may be related to dose and stage of lactation. In early lactation, the addition of ionophores was able to reduce losses of body reserves and increase available energy and animal performance without changing DMI. However, in the mid- and late stages of lactation, as well as in the case of beef cattle, this was able to decrease DMI due to the lower energy requirement (Erasmus et al., 2008).

Although most studies with virginiamycin have been conducted on beef animals in feedlots, some points can be related to dairy cows. Rogers et al. (1995) analyzed seven experiments on dose response for virginiamycin and found an improvement in feed efficiency associated with the mean daily increase in weight gain. None of these studies found a reduction in DMI. However, four experiments found a numerical decrease in DMI, which contributed in part to the improvement in feed efficiency. Furthermore, no increase in $\mathrm{FE}$ was observed in response to doses above $19 \mathrm{mg} \mathrm{kg}{ }^{-1} \mathrm{DM}$, as observed in this study (Table 3). Salinas-Chavira et al. (2009) reported no differences in the average daily gain or DMI for confined Holstein steer calves supplemented with three levels of virginiamycin $\left(0,16\right.$, or $\left.22.5 \mathrm{mg} \mathrm{kg}^{-1}\right)$. 
Table 3 - Dry matter and nutrients intake and nutrient composition considering whole diet daily intake.

\begin{tabular}{|c|c|c|c|c|c|c|c|}
\hline \multirow{2}{*}{ Items } & \multicolumn{4}{|c|}{ Treatments $^{1}$} & \multirow{2}{*}{ Mean } & \multirow{2}{*}{$\mathrm{SEM}^{3}$} & \multirow{2}{*}{$p^{2}$} \\
\hline & C & $S$ & V & SV & & & \\
\hline $\mathrm{DM}_{\mathrm{p}}{ }^{4} \mathrm{~kg} \mathrm{~d}^{-1}$ & $5.80^{\mathrm{a}}$ & $4.00^{b}$ & $4.65^{b}$ & $5.70^{\mathrm{a}}$ & 5.04 & 0.42 & 0.02 \\
\hline $\mathrm{DM}_{\mathrm{s}}^{5} \mathrm{~kg} \mathrm{~d}^{-1}$ & 5.65 & 5.82 & 5.68 & 5.72 & 5.72 & 0.22 & 0.50 \\
\hline $\mathrm{DM}_{\mathrm{T}}^{6} \mathrm{~kg} \mathrm{~d}^{-1}$ & $11.46^{\mathrm{a}}$ & $9.82^{b}$ & $10.33^{b}$ & $11.41^{\mathrm{a}}$ & 10.76 & 0.47 & 0.03 \\
\hline $\mathrm{DM}_{\mathrm{T}}{ }^{6} \% \mathrm{BW}$ & 2.31 & 2.02 & 2.12 & 2.31 & 2.19 & 0.15 & 0.06 \\
\hline $\mathrm{NDFap}^{7} \mathrm{~kg} \mathrm{~d}^{-1}$ & $5.67^{\mathrm{a}}$ & $4.56^{\mathrm{b}}$ & $4.98^{\mathrm{b}}$ & $5.59^{\mathrm{a}}$ & 5.20 & 0.24 & 0.02 \\
\hline NDFap ${ }^{7} \%$ BW & $1.14^{\mathrm{a}}$ & $0.94^{b}$ & $1.02^{\mathrm{b}}$ & $1.13^{\mathrm{a}}$ & 1.06 & 0.04 & 0.02 \\
\hline NDFap7 \% & 48.47 & 46.17 & 48.03 & 48.30 & 47.74 & 1.92 & 0.34 \\
\hline$C P^{8} \mathrm{~kg} \mathrm{~d}^{-1}$ & $1.41^{\mathrm{a}}$ & $1.31^{\mathrm{ab}}$ & $1.25^{\mathrm{b}}$ & $1.38^{\mathrm{a}}$ & 1.62 & 0.06 & 0.04 \\
\hline CP8 \% & $15.13^{a}$ & $15.32^{\mathrm{a}}$ & $15.24^{\mathrm{a}}$ & $14.73^{b}$ & 15.11 & 0.32 & 0.02 \\
\hline $\mathrm{NFC}^{9} \mathrm{~kg} \mathrm{~d}^{-1}$ & 3.14 & 2.73 & 2.76 & 3.06 & 2.92 & 0.30 & 0.19 \\
\hline $\mathrm{NFC}^{9} \%$ & 28.26 & 28.26 & 26.85 & 27.38 & 27.19 & 2.15 & 0.74 \\
\hline $\mathrm{EE}^{10} \mathrm{~kg} \mathrm{~d}^{-1}$ & 0.24 & 0.24 & 0.23 & 0.26 & 0.24 & 0.03 & 0.71 \\
\hline $\mathrm{EE}^{10} \%$ & $2.19^{b}$ & $2.43^{\mathrm{a}}$ & $2.24^{b}$ & $2.30^{\mathrm{b}}$ & 2.29 & 0.06 & $<0.01$ \\
\hline TDN $^{11} \mathrm{~kg} \mathrm{~d}^{-1}$ & $7.75^{\mathrm{a}}$ & $6.50^{\mathrm{b}}$ & $6.83^{\mathrm{b}}$ & $7.51^{\mathrm{a}}$ & 7.15 & 0.28 & 0.04 \\
\hline TDN11 \% & 67.10 & 66.60 & 65.98 & 65.25 & 67.43 & 1.71 & 0.49 \\
\hline $\mathrm{ME}^{12}$ Mcal kg-1 & 2.58 & 2.53 & 2.51 & 2.47 & 2.52 & 0.05 & 0.30 \\
\hline $\mathrm{NE}_{\mathrm{L}}{ }^{13} \mathrm{Mcal} \mathrm{kg}^{-1}$ & 1.62 & 1.59 & 1.57 & 1.54 & 1.57 & 0.05 & 0.30 \\
\hline $\mathrm{S}^{14} \mathrm{mg} \mathrm{kg}^{-1}$ & - & 30.55 & - & 25.82 & - & - & - \\
\hline $\mathrm{V}^{15} \mathrm{mg} \mathrm{kg}^{-1}$ & - & & 35.43 & 32.27 & - & - & - \\
\hline \multicolumn{8}{|c|}{ 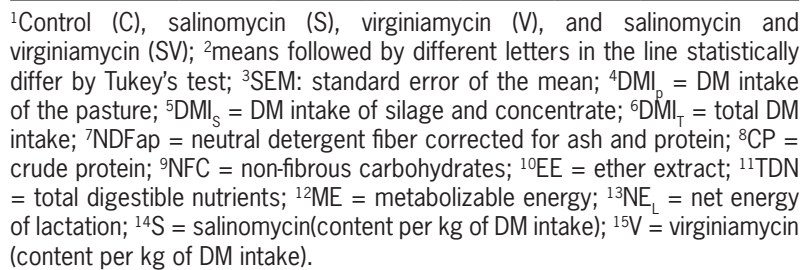 } \\
\hline
\end{tabular}

Few studies conducted with a combination of two antibiotics have found similar results. Nuñez et al. (2013) observed a reduction in DMI with virginiamycin $15 \mathrm{mg}$ $\left.\mathrm{kg}^{-1}\right)$ in the diet containing salinomycin $\left(13 \mathrm{mg} \mathrm{kg}{ }^{-1}\right)$, which contributed to greater FE. On the other hand, Silva et al. (2004) obtained differences in mean daily gain with Nellore steers fed $77 \%$ concentrate diet, supplemented with salinomycin, virginiamycin, or a combination of the two. However, steers receiving both salinomycin and virginiamycin showed higher DMI compared with those supplemented with the isolated additives.

The production of milk and FCM did not differ ( $p$ $>0.05$ ) between treatments (Table 4). Generally, higher yields have been obtained with the use of antibiotics for early-lactation animals. This could be attributed mainly to a decrease in the ratio of acetic to propionic acid, improvement in energy efficiency, and lower mobilization of body reserves (Clayton et al., 1999; Erasmus et al., 2008; Ipharraguerre and Clark, 2003).

Low-production cows such as those used in this experiment, producing less than $13 \mathrm{~kg} \mathrm{~d}^{-1}$ of milk, in the mid-lactation, may show a limited milk response to the use of antimicrobials. Cows in the mid- and late stage of lactation did not change milk production with the use of ionophores (Gandra et al., 2010). However, Gandra et al. (2010) did find increases in FE, to reductions in DMI.
Table 4 - Milk production and composition, feed efficiency and nitrogen and energy balance of experimental diets.

\begin{tabular}{|c|c|c|c|c|c|c|c|}
\hline \multirow{2}{*}{ Items } & \multicolumn{4}{|c|}{ Treatments 1} & \multirow{2}{*}{ Means } & \multirow{2}{*}{ SEM $^{3}$} & \multirow{2}{*}{$p^{2}$} \\
\hline & $C$ & $S$ & V & SV & & & \\
\hline lk kg & 12.62 & 12.42 & 11.82 & 12.24 & 12.28 & 0.6 & 0.4 \\
\hline $\mathrm{M}^{4}$ & 12.40 & 12.44 & 11.81 & 11.99 & 12.16 & 0. & 0.5 \\
\hline$t \%$ & 42 & 3.53 & 3.56 & 3.41 & & & 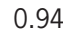 \\
\hline $\mathrm{tk}_{\mathrm{s}}$ & 0.43 & 0.44 & 0.41 & 0.41 & 42 & 0. & 0.8 \\
\hline & 4 & 3.01 & & & & & \\
\hline 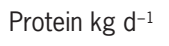 & $0.38^{a}$ & $0.37^{\mathrm{ab}}$ & $0.35^{b}$ & 0.3 & 0.37 & 0. & 0.0 \\
\hline acto & 4.1 & 4.10 & 4.05 & 4. & 1 & 0. & I \\
\hline-1 & 0.52 & 0.51 & 0.48 & 0.5 & 51 & 0. & 0.34 \\
\hline 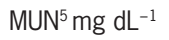 & 9.24 & 9.63 & 9.76 & 8.9 & & 2. & 0.7 \\
\hline$={ }^{6} \mathrm{M}$ & 0.65 & 0.65 & 0.66 & 0.65 & .65 & 0.04 & 0.98 \\
\hline $\mathrm{NE}_{\mathrm{L}}{ }^{6} \mathrm{Mcal} \mathrm{d}^{-1}$ & 8.11 & 8.08 & 7.68 & 7.86 & .93 & 0. & 0.5 \\
\hline$=7$ & $1.08^{b}$ & $1.27^{\mathrm{a}}$ & $1.14^{\mathrm{ab}}$ & $1.05^{\mathrm{b}}$ & 1.14 & 0.07 & 0.04 \\
\hline$E_{f}^{8}$ & $0.49^{b}$ & $0.55^{\mathrm{a}}$ & $0.49^{b}$ & $0.51^{\mathrm{b}}$ & 0.51 & 0.03 & 0.04 \\
\hline 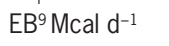 & 0.53 & 0.31 & 0.94 & 0.57 & 0.59 & 1.76 & 0.91 \\
\hline $\mathrm{B}^{10} \mathrm{~g} \mathrm{~d}^{-}$ & 33.86 & 37.31 & 97.23 & 90.95 & 89.84 & 38.11 & 0.97 \\
\hline
\end{tabular}

${ }^{1}$ Control (C), salinomycin (S), virginiamycin (V), and salinomycin and virginiamycin (SV); ${ }^{2}$ means followed by different letters in the line statistically differ by Tukey's test; ${ }^{3} \mathrm{SEM}$ : standard error of the mean; ${ }^{4} \mathrm{FCM}=3.5 \%$ fat corrected milk production; ${ }^{5} \mathrm{MUN}=$ milk urea nitrogen; ${ }^{6} \mathrm{NEL}=$ net energy of lactation excreted in milk; ${ }^{7} \mathrm{FE}=$ feed efficiency (FCM/DMI); ${ }^{8} \mathrm{EE}_{\mathrm{f}}=$ energy efficiency (Mcal of Net energy of lactation excreted in milk/ Mcal of net energy of lactation intake); ${ }^{9} \mathrm{~EB}=$ energy net balance; ${ }^{10} \mathrm{NB}=$ nitrogen balance.

In the present study, $\mathrm{FE}$ was about $18 \%$ higher with salinomycin, compared to the control treatment.

The small amplitude or even absence of responses in DM and nutrient intake with the use of virginiamycin alone or in combination with salinomycin did not contribute to an improvement in feed and energy efficiency. Providing corn silage and concentrate supplement to low-producing cows in mid- to late lactation limited the response in increasing milk or milk composition production with the use of antibiotics. Virginiamycin used alone tended $(p<$ $0.10)$ to increase FE by $6 \%$.

The present experimental diets led to a positive energy and nitrogen balance (Table 4). This indicates that energy and protein requirements were satisfied, and the low milk production was related to the productivity of cows and the stage of lactation. Body-weight changes were positive for all animals, averaging 89, 327, 369 and $61 \mathrm{~g} \mathrm{~d}^{-1}$, respectively, for the control, salinomycin, virginiamycin, and salinomycin with virginiamycin treatments. Measurements of body-weight change help to evaluate the real benefit of additive use, which increases FE without animal weight loss.

Similarly, milk composition (fat, protein and lactose) was not affected $(p>0.05)$ by salinomycin or virginiamycin. Duffield et al. (2008), in a review of monensin, noted that the dose and method of administration, in addition to the stage of lactation, could affect milk composition. The use of antibiotics often reduces amino-acid deamination, and thus losses of nitrogen in urine and milk (McGuffey et al., 2001). Therefore, the observed reduction in milk urea nitrogen (MUN) and increase in milk protein (MP) were 
expected. However, even cows receiving the control diet showed low levels of both components $19.24 \mathrm{mg}$ $\mathrm{dL}^{-1}$ and $3 \%$ ).

Milk urea nitrogen is a valuable tool for monitoring dietary protein (Hof et al., 1997). Levels below $10 \mathrm{mg}$ $\mathrm{dL}^{-1}$ with less than $3.2 \%$ of $\mathrm{MP}$, as observed in this study, may indicate that the diet contained low levels of crude protein and rumen-degradable protein (RDP).

Animals were supplemented with corn silage and a supplement concentrate with high energy content that requires higher $\mathrm{CP}$ and RDP diets. The commercial concentrate with $220 \mathrm{~g} \mathrm{~kg}^{-1} \mathrm{CP}$ used here may have not met the animals' RDP requirements, which probably influenced the MUN and MP levels and the lack of antibiotic effects.

The inclusion of antimicrobials did not affect DM and nutrient digestibility $(p>0.05)$ of the experimental diets, except for NDF digestibility (Table 5). The effect of virginiamycin on DM digestibility has rarely been investigated (Salinas-Chavira et al., 2009). These authors observed an improvement in DM digestibility in swine, which was attributed to an increase in intestinal feed retention and a reduction in harmful bacteria (Ravindran et al., 1984).

Ionophores could improve fiber digestibility, mainly because they reduce feed intake and consequently affect the passage rate of solids. However, NDF digestibility was lower $(p=0.02)$ when the combined antibiotics were used, compared to the control diet $(\mathrm{C})$, or to salinomycin alone (S). Lower fiber digestibility in this case may be related to the tendency for ammonia reduction with the use of virginiamycin.

Rumen ammonia nitrogen levels (RAN) were similar $(p>0.05)$ in the experimental diets, above $8 \mathrm{mg} \mathrm{dL} \mathrm{d}^{-1}$ - the minimum needed to maximize fiber degradation. A reduction of ruminal ammonia and blood urea nitrogen (BUN) with antibiotics would be expected, due to the reduction in amino acid deamination.

Table 5 - Values of dry matter digestibility, $\mathrm{pH}$, ammonia nitrogen and blood urea.

\begin{tabular}{|c|c|c|c|c|c|c|c|}
\hline \multirow{2}{*}{ Items } & \multicolumn{4}{|c|}{ Treatments $^{1}$} & \multirow{2}{*}{ Means } & \multirow{2}{*}{$\mathrm{SEM}^{3}$} & \multirow{2}{*}{$p^{2}$} \\
\hline & $C$ & $S$ & V & SV & & & \\
\hline $\mathrm{DM}^{4}$ & 65.62 & 66.20 & 65.26 & 64.19 & 5.32 & 2. & 0.15 \\
\hline $\mathrm{CP}^{4}$ & 71.44 & 73.22 & 73.01 & 70.25 & 7 & 2. & 0.22 \\
\hline $\mathrm{NDF}^{4}$ & $64.20^{\mathrm{a}}$ & $63.46^{a}$ & $61.48^{\mathrm{ab}}$ & $60.01^{b}$ & 62. & 3. & 0.02 \\
\hline$E^{4}$ & 80.05 & 77.33 & 78.82 & 80. & 79 & 7. & 0.5 \\
\hline $\mathrm{NFC}^{4}$ & 77.47 & 76.69 & 78.97 & 79.60 & 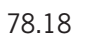 & 2. & 0.41 \\
\hline$A N^{5}$ & $11.46^{\mathrm{a}}$ & $11.01^{\mathrm{a}}$ & $9.86^{b}$ & $9.54^{b}$ & 10.94 & 1.4 & 0.09 \\
\hline $\mathrm{pH}^{6}$ & 6.5 & 6.4 & 6.5 & 6.6 & .5 & 0.15 & 0.21 \\
\hline BUN7 & 20.78 & 22.17 & 19.85 & 19.36 & 20.54 & 4.96 & 0.53 \\
\hline
\end{tabular}

${ }^{1}$ Control (C), salinomycin (S), virginiamycin (V), and salinomycin and virginiamycin (SV); ${ }^{2}$ means followed by different letters in the line statistically differ by Tukey's test; ${ }^{3} \mathrm{SEM}=$ standard error of mean; ${ }^{4} \mathrm{DDM}=$ digestibility coefficient of total dry matter; DCP = digestibility coefficient of crude protein; DNDF = digestibility coefficient of neutral detergent fiber; DEE = digestibility coefficient of ether extract; DNFC = digestibility coefficient of non-fibrous carbohydrates; ${ }^{5} \mathrm{RAN}=$ ruminal ammonia nitrogen; ${ }^{6} \mathrm{pH}=$ ruminal $\mathrm{pH} ;{ }^{7} \mathrm{BUN}$ $=$ blood urea nitrogen.
Although not significant $(p>0.05)$, the addition of virginiamycin decreased RAN by $14 \%$ and reduced it to below $8 \mathrm{mg} \mathrm{dL}^{-1}$ for a long period during the day (Figure 1). Moreover, a $9 \%$ BUN reduction was observed, compared to the control diet. In this study, mean levels of BUN were $20.54 \mathrm{mg} \mathrm{dL}^{-1}$, i.e., approximately at the limit of $19-20 \mathrm{mg} \mathrm{dL}^{-1}$ at which dietary nitrogen losses could occur in dairy cows (Oliveira et al., 2001).

No differences were observed $(p>0.05)$ in ruminal $\mathrm{pH}$ between diets (Table 5). The $\mathrm{pH}$ of high-forage diets did not change with the addition of antimicrobials (Clayton et al., 1999). Grazing, ruminating and iddle times did not differ $(p>0.05)$ between experimental diets (Table 6). Other parameters such as pasture selection and bite size influenced the intake rates, as salinomycin or virginiamycin reduced pasture intake without affecting grazing time.

Grazing time reflects the ease of forage access and removal. The time spent grazing varies between 359 and $711 \mathrm{~min}^{-1}$ (Krysl and Hess, 1993), and grazing times

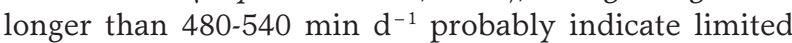
conditions for forage intake (Hodgson, 1990). In this study, the mean grazing time was $328 \mathrm{~min}^{-1}$, as a result of good quality forage (Table 2), pasture availability (Table 1) and the provision of part of the diet in feeders.

The addition of salinomycin or virginiamycin for mid-lactation dairy cows improved $\mathrm{FE}$, because it reduced DMI without affecting milk production and milk composition.

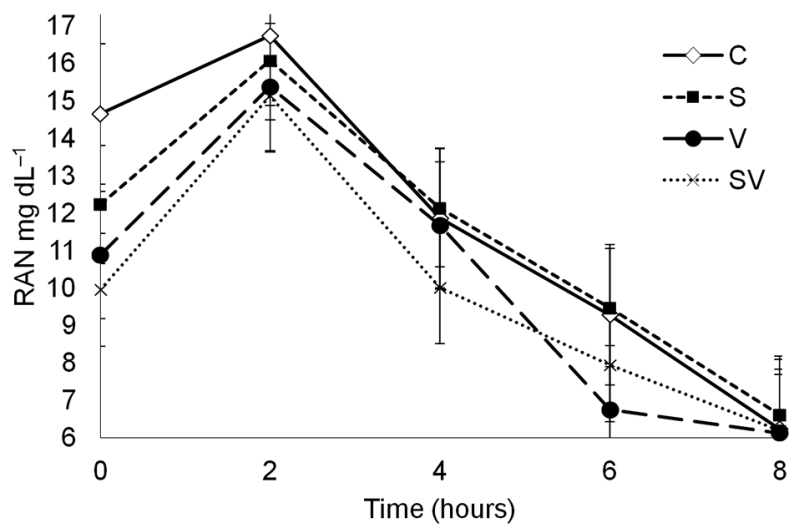

Figure 1-Ruminal Ammonia Nitrogen (RAN) before 0, and at 2, 4, 6 and $8 \mathrm{~h}$ after feeding in control (C), salinomycin (S), virginiamycin (V), and salinomycin and virginiamycin (SV). Bars show the standard error of mean.

Table 6 - Feeding behavior of lactating dairy cows $\left(\min ^{-1}\right)$.

\begin{tabular}{lccccccc}
\hline \multirow{2}{*}{ Variables } & \multicolumn{9}{c}{ Treatments $^{1}$} & & \multirow{2}{*}{ Means } & SEM $^{3}$ & $p^{2}$ \\
\cline { 2 - 5 } & C & S & V & SV & & & \\
\hline Grazing & 295 & 316 & 324 & 301 & 328 & 42 & 0.12 \\
Rumination & 539 & 537 & 559 & 567 & 550 & 27 & 0.33 \\
Iddle & 549 & 529 & 496 & 501 & 519 & 38 & 0.13 \\
\hline
\end{tabular}

${ }^{1}$ Control (C), salinomycin (S), virginiamycin (V), and salinomycin and virginiamycin (SV); ${ }^{2}$ means followed by different letters in the line statistically differ by Tukey's test; ${ }^{3}$ SEM: standard error of the mean. 


\section{References}

Association of Official Analytical Chemists [AOAC]. 2005. Official Methods Of Analysis. 18ed. AOAC, Gaithersburg, MD, USA.

Bagley, C.P.; Feazel, J.I.; Morrison, D.G.; Lucas, D.M. 1988. Effects of Salinomycin on Ruminal characteristics and performance of grazing beef steers. Journal of Animal Science 66: 792-797.

Boon, B.; Dewart, R. 1974. Methods for identification and assay of virginiamycin in animal feeds. Analyst 99: 19-25.

Clayton, E.H.; Lean, I.J.; Rowe, J.B.; Cox, J.W. 1999. Effects of feeding virginiamycin and sodium bicarbonate to grazing lactating dairy cows. Journal of Dairy Science 82: 1545-1554.

Detmann, E.; Paulino, M.F.; Zervoudakisi, J.T.; Valadares Filho, S.C.; Euclydes, R.F.; Lana, R.P.; Queiroz, D.S. 2001. Chromium and internal markers in intake determination by crossbred steers, supplemented at pasture. Brazilian Journal of Animal Science 30: 1600-1609 (in Portuguese, with abstract in English).

Duffield, T.F.; Rabiee, A.R.; Lean, I.J. 2008. A meta-analysis of the impact of monensin in lactating dairy cattle. Part 2. Production effects. Journal of Dairy Science 91:1347-1360.

Erasmus, L.J.; Muya, A.C.; Erasmus, A.S.; Coertze, B.R.F.; Catto, B.D.G. 2008. Effect of virginiamycin and monensin supplementation on performance of multiparous Holstein cows. Livestock Science 119: 107-115.

Gandra, J.R.; Rennó, F.P.; Freitas Júnior, J.E.; Santos, M.V.; Silva, L.F.P.; Araújo, A.P.C. 2010. Productive performance and milk protein fraction composition of dairy cows supplemented with sodium monensin. Brazilian Journal of Animal Science 39: 1810-1817 (in Portuguese, with abstract in English).

Hall, M.B. 2000. Calculation of Non-Structural Carbohydrate Content of Feeds That Contain Non-Protein Nitrogen. University of Florida, Gainesville, FL, USA. (Bulletin, 339 A-25).

Hodgson, J. 1990. Grazing Management: Science into Practice. Longman, Essex, UK.

Hof, G.; Vervoorn, M.D.; Lenaers, P.J.; Tamminga, S. 1997. Milk urea nitrogen as a tool to monitor the protein nutrition of dairy cows. Journal of Dairy Science 80: 3333-3340.

International Dairy Federation [IDF]. 1996. Whole milk determination of milk fat, protein and lactose content: guide for the operation of mid-infrared instruments. IDF, Brussels: IDF, Belgium.

Ipharraguerre, I.R.; Clark, J.H. 2003.Usefulness of ionophores for lactating dairy cows: a review. Animal Feed Science and Technology 106: 39-57.

Krysl, L.J.; Hess, B.W. 1993. Influence of supplementation on behavior of grazing cattle. Journal of Animal Science 71: 25462555.

Licitra, G.; Hernandez, T.M.; Soest, P.J. van. 1996. Standardization of procedures for nitrogen fractionation of ruminant feeds. Animal Feed Science and Technology 57: 347-358.
McGuffey, R.K.; Richardson, L.F.; Wilkinson, J.I.D. 2001. Ionophores for dairy cattle: current status and future outlook. Journal of Dairy Science 84 Suppl.: E194-E203.

Merchen, N.R.; Berger, L.L. 1985. Effect of salinomycin level on nutrient digestibility and ruminal characteristics of sheep and feedlot performance of cattle. Journal of Animal Science 60: 1338-1346.

Mertens, D.R. 2002. Gravimetric determination of amylasetreated neutral detergent fiber in feeds with refluxing in beakers or crucibles: collaborative study. Journal of AOAC International 85: 1217-1240.

Mertens, D.R. 1987. Predicting intake and digestibility using mathematical models of ruminal function. Journal of Animal Science 64: 1548-1558.

National Research Council [NRC]. 2001. Nutrient Requirements of Dairy Cattle. 7ed. National Academies Press, Washington, DC, USA.

Nuñez, A.J.C.; Caetano, M.; Berndt, A.; Demarchi, J.J.A.A.; Leme, P.R.; Lanna, D.P.D. 2013. Combined use of ionophore and virginiamycin for finishing Nellore steers fed high concentrate diets. Scientia Agricola 70: 229-236.

Oliveira, A.S.; Valadares, R.F.D.; Valadares Filho, S.C.; Cecon, P.R.; Rennó, L.N.; Queiroz, A.C.; Chizzotti, M.L. 2001. Microbial protein production, purine derivatives and urea excretion estimate in lactating dairy cows fed isoprotein diets with different non protein nitrogen compounds levels. Brazilian Journal of Animal Science 30: 1621-1629 (in Portuguese, with abstract in English).

Ravindran, V.; Kronegay, E.T.; Webb Jr, K.E. 1984. Effects of fiber and virginiamycin on nutrient absorption, nutrient retention, and rate of passage in growing swine. Journal of Animal Science 59: 400-408.

Rogers, J.A.; Branine, M.E.; Miller C.R.; Wray, M.I.; Bartle, S.J.; Preston, R.L.; Gill, D.R.; Pritchard, R.H.; Stilborn, R.P.; Bechtol, D.T. 1995. Effect of dietary virginiamycin on performance and liver abscess incidence in feedlot cattle. Journal of Animal Science 73: 9-20.

Salinas-Chavira, J.; Lenin, J.; Ponce, E.; Sanchez, U.; Torrentera, N.; Zinn, R.A. 2009. Comparative effects of virginiamycin supplementation on characteristics of growth-performance, dietary energetics, and digestion of calf-fed Holstein steers. Journal of Animal Science 87: 4101-4108.

Silva, S.L.; Almeida, R.; Schwahofer, D.; Leme, P.R.; Lanna, D.P.D. 2004. Effects of salinomycin and virginiamycin on performance and carcass traits of feedlot steers. Journal of Animal Science 82: 41-42.

Sklan, D.; Ashkenazi, R.; Braun, A.; Devorin, A.; Tabori, K. 1992. Fatty acids, calcium soaps of fatty acids, and cottonseeds fed to high yielding cows. Journal of Dairy Science 75: 2463-2472. 